\title{
Ischemia and reperfusion in skin flaps: effects of mannitol and vitamin $C$ in reducing necrosis area in a rat experimental model ${ }^{1}$
}

\author{
Isquemia e reperfusão de retalhos cutâneos: efeitos do manitol e vitamina C \\ na redução de áreas de necrose em modelo experimental no rato
}

\author{
Winston Bonetti Yoshida² ${ }^{2}$ Eloísa Bueno Pires de Campos ${ }^{3}$ \\ 1. Department of Surgery and Orthopedics, Medical School - UNESP. Botucatu, São Paulo State University, Brazil. \\ 2. Associate Professor of Surgery - UNESP. Botucatu, São Paulo - Brazil. \\ 3. Master Post-Graduate Program in Surgery, Plastic Surgeon. Botucatu, São Paulo - Brazil.
}

\begin{abstract}
Purpose: The aim of the present study was to develop an experimental model of ischemia-reperfusion injury in rat skin flap and to verify the effect of mannitol and vitamin $C$ on reducing necrosis area. Methods: A 6-x 3-cm groin skin flap was raised and submitted to 8 hours of ischemia by clamping the vascular pedicle and to 7 days of reperfusion. The animals were divided in four groups: $\mathrm{S}_{1}$ and $\mathrm{S}_{2}$ (10 animals each) and $\mathrm{C}$ and $\mathrm{T}$ (14 animals each). In groups $\mathrm{S}_{1}$ and $\mathrm{S}_{2}$ skin flaps were not submitted to ischemia and animals received lactated Ringer's solution $\left(\mathrm{S}_{1}\right)$ and antioxidant solution $\left(\mathrm{S}_{2}\right)$. In groups $\mathrm{C}$ and T, flaps were subjected to 8 hours of warm ischemia and animals received Lactated Ringer's solution (Group C) and antioxidant solution immediately before reperfusion, (Group T). Flap survival was evaluated on the seventh day using a paper template technique and computer-assistant imaging analysis of necrotic and normal areas. Results: Statistical analysis showed no area differences between groups $\mathrm{C}$ and T. Conclusion: The experimental model provided consistent necrotic area in control groups and drugs used were not effective in improving skin flap survival.
\end{abstract}

Key words: Ischemia. Reperfusion. Mannitol. Ascorbic acid. Surgical flaps. Rats.

\begin{abstract}
RESUMO
Objetivo: Neste trabalho foi padronizado modelo experimental de isquemia e reperfusão em retalho cutâneo em ratos no qual estudou-se possibilidade de uma solução antioxidante, composta por Ringer lactato, vitamina C e manitol de reduzir a área de necrose. Métodos: O modelo consistiu de levantamento de retalho cutâneo axial de 6,0 x 3,0cm, submetido à isquemia de 8 horas e reperfusão de 7 dias. Os animais foram divididos em quatro grupos: grupos $S_{1} S_{2}(10$ animais cada), C e T (14 animais cada). Nos grupos S1 e S2 todos os procedimentos dos demais grupos foram efetuados, exceto a isquemia e reperfusão: $S_{1}$ recebeu apenas Ringer lactato e $S_{2}$ a solução antioxidante. Os grupos $C$ e $T$ foram submetidos à isquemia. $\mathrm{O}$ grupo $\mathrm{C}$ recebeu somente Ringer lactato e o grupo $\mathrm{T}$ a solução antioxidante. No $7^{0}$ dia de pós-operatório as áreas de necrose e pele viável do retalho foram delineadas em decalque de acetato, os quais foram por sua vez analisados em sistema computadorizado KS-300 (Carl Zeiss). Resultados: A análise estatística mostrou que não houve diferenças significativas entre o grupo tratado e controle quanto à área de necrose. Conclusão: Concluiu-se que o modelo experimental é consistente, determinando área de necrose limitada e uniforme nos animais não tratados e que as drogas usadas, nessa posologia e modo de aplicação, não foram efetivas em diminuir a área de necrose no modelo experimental em questão.

Descritores: Isquemia. Reperfusão. Manitol. Ácido ascórbico. Retalhos cirúrgicos. Ratos.
\end{abstract}

\section{Introduction}

With the development of microsurgery, possibilities of reconstructions once impossible increased, and the evolution of free tissue transfer started and revolutionized several surgery specialties, in particular reconstructive plastic surgery and vascular surgery. Today, it is known that frequency of pervious microsurgical vascular anastomoses, even with experienced surgeons, is of 90 to $95 \%$. Occlusions generally result from technical error or vascular thrombosis and, in these cases, a surgical approach that consists of thrombectomy, revision of anastomosis and restoration of blood flow is necessary.
However, restoration of normal vascular supply can paradoxically be responsible for injuries even more severe than those caused by ischemia itself. Based on studies by Granger $^{1}$, it was discovered that oxygen afflux on ischemic tissue would lead to a series of biochemical, inflammatory and cellular alterations mediated mainly by release of oxygen free radicals. These alterations have been largely studied in experimental models in which different treatments are used to reduce particularly post-reperfusion skin necrosis. Thus, superoxide-dismutase ${ }^{2}$, allopurinol ${ }^{3}$, washout of entire vascular territory of epigastric flaps have been tested in rats with lactated Ringer's solution ${ }^{4}$ or solution of University of Wisconsin (UW), verapamil, urokinase and iloprost ${ }^{5}$, 
deferoxamine, vitamin $\mathrm{C}^{6}$, mannitol and anisodamin ${ }^{7}$, immunosuppressants ${ }^{8}$, immunosuppressant and dexamathasone $^{9}$, blocker agents of histamine receptors ${ }^{10}$, Vitamins $\mathrm{E}$ and $\mathrm{A}^{11}$, prostaglandin $\mathrm{E} 1^{12}$, trimetazidin ${ }^{13}$, NO donors ${ }^{14,15}$, platelet of GIIb/IIIa receptors antagonists ${ }^{16}$, nitrosogluthatione modulation, NO synthase expression ${ }^{17}$, sulfatides $^{18,19}$, fucoidin ${ }^{20}$, acethylcysteine ${ }^{21}$. There is, therefore, great interest in this theme, as ischemiareperfusion phenomenon of skin flaps frequently occurs in microsurgery and for which still there is not today a defined conduct to improve evolution of flaps. There is much to study and compare drugs that may prevent or correct the consequences of this process. Although several drugs have shown good results experimentally, in clinical practice there is not a consensus treatment. Some drugs, such as deferoxamine, allopurinol, and immunosuppressant agents may cause important side effects, which justify the need to study more effective drugs without, however, harmful repercussions for the organism.

Bearing in mind the therapeutic simplicity and success of mannitol and vitamin C used separately in some models, we have decided to test an antioxidant preserving solution made of both mannitol and vitamin $\mathrm{C}$ diluted in lactated Ringer's solution and to verify if its use could reduce area of skin necrosis in skin flaps after eight hours of ischemia followed by 7 days reperfusion.

\section{Methods}

Local Ethics Commission in Animal Experiments approved the experiment. Fifty-eight male Wistar rats, 90 days old, were used, 48 of which were used in the definitive experiment. Rats were anesthetized with intraperitoneal pentobarbital sodium $(35 \mathrm{mg} / \mathrm{kg}$ ) and then submitted to abdominal shaving and placed on supine position. A flat template measuring $6 \times 3 \mathrm{~cm}\left(18 \mathrm{~cm}^{2}\right)$ was positioned and the skin marked with a pencil. The marked skin flap was elevated deep to the panniculus carnosus on the left abdominal region with vascularization and drainage coming from left superficial inferior epigastric veins (Figures 1A and 1B). The superficial inferior branch of femoral nerve was not sectioned. Flap was submitted to eight hours of ischemia by using microvascular clamp at the epigastrium pedicle (Figure 1C). Flap was repositioned on its original bed with a latex interposition to avoid nutrition of the flap by contact to wound bed itself (Figure 1D). Flap was sutured with continuous suture of a 4-0 monofilament polyamide, except on caudal border where simple stitches were used to make posterior removal of clamp easier. A rodent restraint cone was then placed. Animals were kept in cages with free access to water and food. Close to the end of the ischemia period, animals were anesthetized again, submitted to dissection and catheterization of right jugular vein. Fifteen minutes before clamp was released, rats received intravenously through the jugular catheter, the solution according to group by infusion pump set to infusion speed of $0,5 \mathrm{ml}$ per minute. Average time of infusion was 4 minutes.

After eight hours of ischemia, vascular clamp was removed allowing flap to reperfuse (Figure 1E). The latex interposition was also removed. Vascular pedicle was observed for 30 minutes for the presence of thrombosis signs. Animals, in which suggestive local signs of thrombosis were identified, were excluded from the experiment. After surgery, animals were kept in individual cages with rodent restraint cones for 7 days. Animals were then anesthetized to measure skin area being studied using a paper template technique and fixing perimeters of flap and of necrotic portion (Figure 1F). After that, rats received a lethal dose of anesthetic.

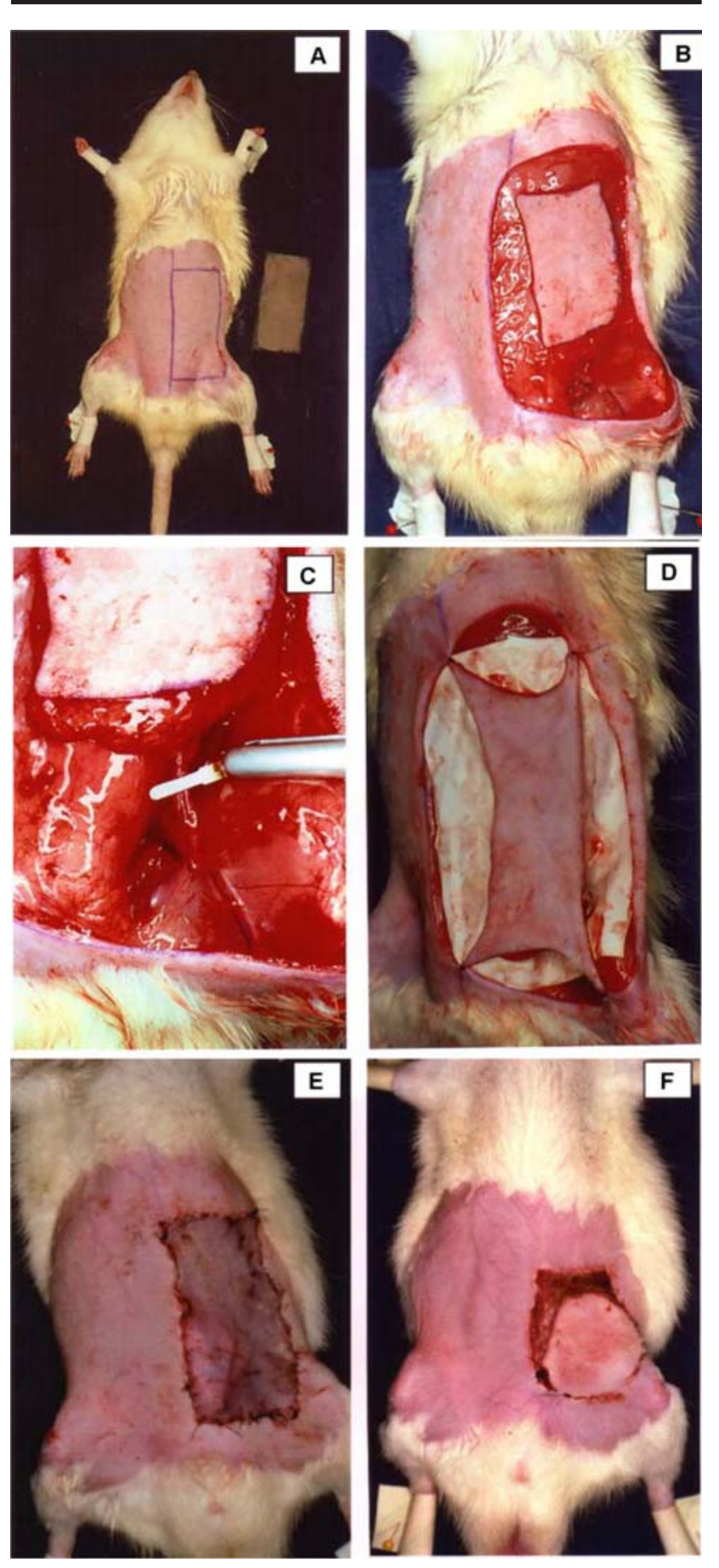

FIGURE 1 - Experimental procedures. A - Flap demarcation; B - skin incision; C - Vascular pedicle clamping; D - Suture of the skin flap, with a latex interposition; E - follow-up after 8hr ischemia; F - Follow-up after 7 days of reperfusion 
Animals were divided into 4 groups of 12 animals:

Group C (control): animals had flaps raised, sutured back and submitted to ischemia for eight hours. Fifteen minutes prior to reperfusion, they received intravenously lactated Ringer's solution.

Group T (treated): animals had flaps raised, sutured back and submitted to ischemia for eight hours. Fifteen minutes prior to reperfusion, they received intravenously antioxidant solution made of lactated Ringer's solution (7,5 $\mathrm{ml} / \mathrm{kg}$ body weight), mannitol ( $0,24 \mathrm{ml} / \mathrm{kg}$ body weight) and vitamin C (10 ml/kg body weight) with infusion speed of 0,5 ml per minute.

Group $\mathrm{S}_{\mathbf{1}}$ : animals had the same surgical procedures of treatment groups, except ischemia and reperfusion and received intravenously lactated Ringer's solution $(7,5 \mathrm{ml} /$ $\mathrm{kg}$ body weight) soon after simulation of ischemia period ended with infusion speed of $0,5 \mathrm{ml}$ per minute.

Group $\mathbf{S}_{2}$ : animals had same surgical procedures of treatment group, except ischemia and reperfusion as in group $S_{1}$ and received intravenously, in the same way, the same solution as group $\mathrm{T}$ soon after simulation of ischemia period ended.

Solutions were prepared and injected by the experimental laboratory assistant without researcher knowledge of the drug infused. After 7 days, paper templates of flaps were made, and flap areas and skin necrosis areas were calculated in the computer-assisted imaging equipment KS 300 Image Analyses System (Figure 2). Student-t test for independent samples was used to compare mean areas of groups.

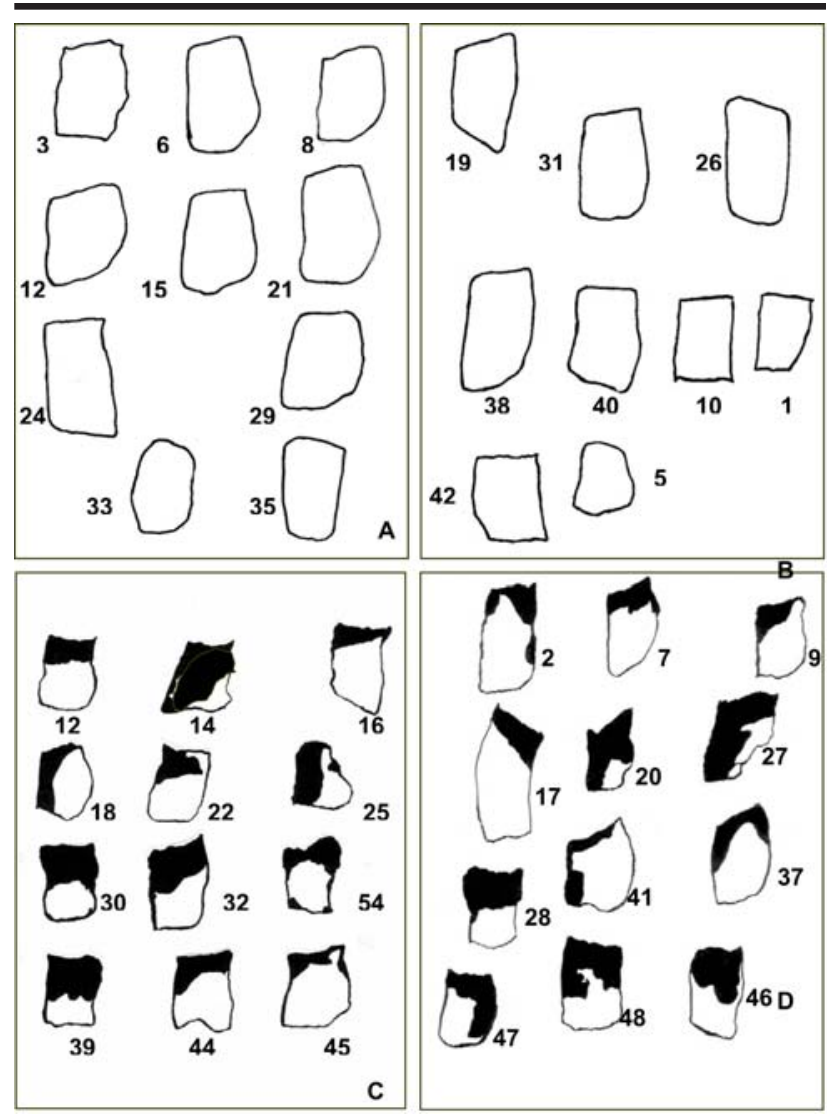

FIGURE 2 - Template diagrams of each experimental group: A - Group S1; B - Group S2; C - Group C; D - Group T.

\section{Results}

Four deaths occurred in the immediate post-surgical period: two animals from group $\mathrm{T}$, one from group $\mathrm{C}$ and one from group $\mathrm{S}_{2}$. One animal from group $\mathrm{C}$ was discarded due to auto-cannibalism of the flap. Thrombosis in pedicle flap occurred in three animals and flap infection occurred in two other ones. With the exception of simulated groups (sham operated), these animals were replaced and the number of animals per group was completed. Total flap areas of groups $\mathrm{S}_{1}$ and $\mathrm{S}_{2}$ did not show statistically significant differences between them, and those of groups $\mathrm{C}$ and $\mathrm{T}$ did not show differences between them either $(p>0,10)$. However, mean areas of groups submitted to ischemia ( $\mathrm{C}$ and $\mathrm{T}$ ) reduced practically to half of the two other groups $(\mathrm{p}<0,05)$ (Figure 3). Necrosis areas occurred only in groups $\mathrm{C}$ and $\mathrm{T}$ without statistically significant differences between the two groups $(\mathrm{p}>0,10)$.

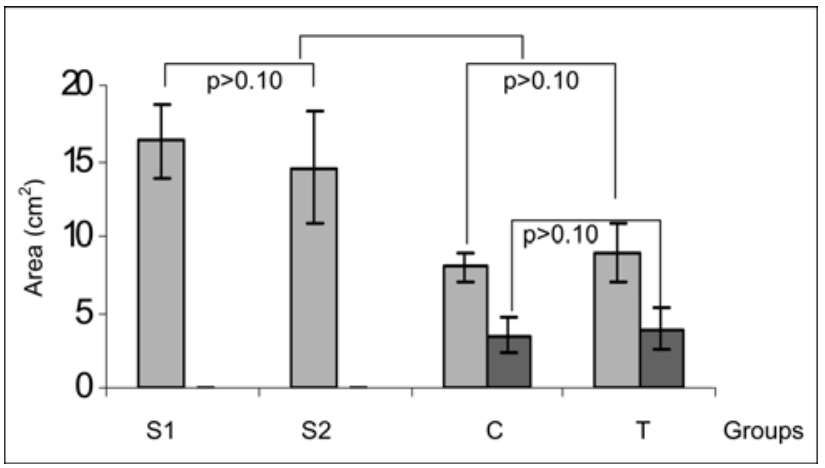

FIGURE 3 - Areas of the flaps and necrosis after 7 days: means and standard deviations of each group. Light gray = areas without necrosis; dark gray $=$ areas with necrosis.

\section{Discussion}

As to the model chosen, it was intended to simulate a clinical situation that occurs when a microsurgical tissue transference is made and in which the flap is submitted to a ischemia period (vascular pedicle is sectioned and anastomosed in another receptor vein), followed by blood reperfusion. The model would also simulate what happens when reimplantation of traumatically amputated fingers is made. The model could also simulate a vascular pedicle thrombosis in which period from diagnosis to reintervention and reestablishment of vascular supply could reach and even exceed eight hours. The epigastric flap model has been widely used in experimental studies about ischemia and reperfusion. Flap dimensions in this type of study range from $6 \mathrm{~cm}$ in length by $4 \mathrm{~cm}$ in width ${ }^{22,23}$, from $6.0 \times 3,5 \mathrm{~cm}^{6}$ and from $6,0 \times 3,0 \mathrm{~cm}^{4,5,24}$. In all of these models, flaps were made of skin, paniculus carnosus, subcutaneous cell tissue and fascia with vascular pedicle represented by superficial inferior epigastric artery and vein. The experimental model developed in this study also had flap made of skin, paniculus carnosus, subcutaneous cell tissue and fascia based on superficial inferior epigastric veins and measuring 6,0 x 3,0 
in extension. There are controversies as to where microvascular clamps are positioned. They could be used only on the vein or only on the artery to simulate other situations that may happen in clinical practice in which thrombosis may occur in any of pedicle elements. Fontana et al. ${ }^{25}$ compared the effect of the drug mercaptopropionylglycine to increase survival of skin flaps in rats which were divided in three groups: with obstruction of artery, of vein and of both of them and verified that results were progressively better in groups with obstruction of only the artery, of the artery and vein together and only of the vein. Authors attributed such finding to a probable greater release of free radicals in the group submitted to occlusion of the vein in relation to the others, possibly because of the persistent afflux of oxygen through the artery and by the extravasation of metallic ions which would favor Fenton reaction ${ }^{1}$, another factor which would contribute to the increase of free radicals. In the literature, the period of "warm" ischemia (so called when skin is contact with the animal) varied from 6 to 18 hours ${ }^{4,6}$. In studies of "cold" ischemia made to test tissue storage, flaps were kept cooled for up to six days ${ }^{26}$. In this study, we opted for a period of 8 hours of ischemia, which proved adequate in the pilot study. Wang et al. ${ }^{27}$ compared survival rate of epigastric skin flaps in rats submitted to ischemia and reperfusion for 1, 6 and 10 hours with or without a synthetic pellicle interposed between flap and bed and observed a longer survival of flaps in the absence of the pellicle. Based on this finding, in the present study, a latex fragment with larger dimensions than the flap was interposed. After this maneuver, our results in the pilot study were also more consistent as to the presence of homogenous necrosis in flaps submitted to ischemia and reperfusion without treatment. Treatment results of the present study were evaluated using the clinical method described by Sasaki e Pang ${ }^{28}$ in which the necrotic area and the survival area of the flap were measured by a paper template placed on the abdominal area of the animal and traced by the experimenter. This method was chosen for its simplicity and sensibility and also for being particularly accurate when dimensions of the area are calculated by computer system. The use of pharmacological agents to increase tolerance of organs and tissue to ischemia and reperfusion was, and it still is, largely studied in experimental studies. We chose to use in this present study an antioxidant solution made of mannitol and vitamin $\mathrm{C}$ diluted in lactated Ringer's solution: two drugs whose effects are known and which have already been used in skin flaps with favorable results, which have low cost and that are normally used in clinical practice for other purposes. According to Niki et al. ${ }^{29}$, vitamin $\mathrm{C}$ has an antioxidant effect of the superoxide and hydrophilic radicals and it also acts on limiting lipidic peroxidation with the advantage of being reused through reversible reaction of oxide-reduction:

\section{Ascorbic acid or $\longrightarrow$ Dehydroascorbic acid or}

Reduced vitamin $\mathrm{C} \Longleftarrow$ Oxidized vitamin C

Vitamin C diluted in saline was used separately in experiments on skin flaps in the dose of $67 \mathrm{mg} / \mathrm{kg}$, administered in rat femoral artery 15 minutes prior to reperfusion and covering the whole flap ${ }^{6}$. Although results of this study showed, in average, greater stability and survival of the flap in the treated group, variation of viable area was very large (from 0 to $73 \%$ ), that is, it was not uniform. Authors attributed such result to several variables present in the process of ischemia and reperfusion and concluded that the association of antioxidants could probably produce better results. Mannitol is a monosaccharide alcohol $\left(\mathrm{C}_{6} \mathrm{H}_{14} \mathrm{O}_{6}\right)$ known for its diuretic-osmotic effect and for reducing cerebral edema. It is also currently used as a specific antioxidant of hydroxyl radical ${ }^{30}$.

In experimental study in rabbits by Ouriel et $\mathrm{al}^{31}$, the antioxidant effect of mannitol, specially of the hydroxyl radical, in ischemia and reperfusion of cardiac muscle was demonstrated independently of its osmolars properties. Paterson $^{32}$ demonstrated in a clinical study that mannitol inhibited synthesis of thromboxane, which would activate neutrophils to release cytokines, and demonstrated thus a second beneficial action in the process of ischemia and reperfusion. The beneficial effect of mannitol was observed in several ischemia-reperfusion situations and ischemia and reperfusion in skin flaps in rabbits ${ }^{7,33}$. Based on these results, vitamin $\mathrm{C}$ and mannitol were chosen as antioxidants for the present study. There are controversies also as to the administration route of the drug. Some authors defend that a simple washout of flap vascular territory with crystalloid solution ${ }^{4}{ }^{34}$ separately could be enough to remove blood and metabolites from flap, including free radicals. Most authors prefer to use the chosen antioxidant solution applied to the flap vascular bed ${ }^{5}$. Others chose systemic intravenous administration of the drug ${ }^{25}$ because of reduced diameter of veins and excessive manipulation , flap losses due to vascular thrombosis were high. It was also chosen for its easiness in being administered intravenously clinically. The time used to administer drugs (15 minutes prior to reperfusion) was based on the experiment by Zaccaria et al. ${ }^{6}$ who also used vitamin C. Although studies using mannitol have administered it at the time of reperfusion ${ }^{35,36}$, we chose to administer it prior to reperfusion as both drugs were combined. In the study by Ueno et al. ${ }^{37}$, drugs were administered immediately before releasing blood flow, but there are studies in which drugs are administered up to 30 minutes prior to blood flow release ${ }^{9}$.

The dose of vitamin $\mathrm{C}$ and mannitol used in this study was the same as the one used by Ueno et $\mathrm{al}^{37}$. Zaccaria et al. ${ }^{6}$, however, used a dose of vitamin $\mathrm{C}$ six times higher. It is possible that the result of the present study could have been different if the drugs had been administered in higher dosages or directly into flap vascular territory. As to the dose of mannitol used in this study, compared to the study by Oredsson et al. ${ }^{36}$, it was twice as higher. But, still, it should be considered that the time of administration was premature in this study since $\mathrm{Fu} \& \mathrm{Jiao}^{7}$ recommended administration of mannitol immediately before reperfusion. Yokoyama et $\mathrm{al}^{38}$ dosed superoxide radical in effluent vein of rabbit limb submitted to several periods of ischemia during 60 minutes of reperfusion and found a late polyphasic pattern (several peaks) of release of free radicals $(20,30,40$ to 50 minutes of reperfusion). A different result was found by Tortolani et al. ${ }^{39}$ who demonstrated a biphasic profile ( 5 to 10 minutes and 25 minutes). These results must be considered in relation to doses, time and duration of drug 
administration since release of free radicals varies according to time of ischemia and organ or tissue. Release probably starts via xanthine oxidase and on the second peak by activation of neutrophils that produce superoxide through NADPH oxidation. As reactions are chain reactions, it is not strange to find a polyphasic pattern, but what can be said is that there still is a long path in the search of ways to correct harmful effects of ischemia-reperfusion process.

Therefore, overcoming effects of ischemia and reperfusion is still a challenge for researchers and it is probable that the association of drugs acting in several ways, such as antioxidants, NOS inhibitors (oxide nitric synthetase), vasodilators and anti-aggregating platelet agents should be investigated.

\section{Conclusions}

The experimental model of ischemia and reperfusion resulted in the appearance of skin necrosis area, which was uniform and constant with limited extension and slightly variable, simulating clinical alterations resulting from ischemia and reperfusion. In this experimental model, and in the doses used, the antioxidant solution made of mannitol and vitamin C diluted in lactated Ringer's solution did not prevent nor reduced the necrosis area in relation to control group treated only with lactated Ringer's solution.

\section{References}

1. Granger DN, Hollwarth ME, Parks DA. Ischemiareperfusion injury: role of oxygen-derived free radicals. Acta Physiol Scand. 1986;548:47-63.

2. Manson PN, Narayan KK, Im MJ, Bulkley GB, Hoopes JE. Improved survival in free skin flap transfers in rats. Surgery.1986;99:211-5.

3. Im MJ, Shen WH, Pak CJ, Manson PN, Bulkley GB, Hoopes JE. Effect of allopurinol on the survival of hyperemic island skin flaps. Plast Reconstr Surg. 1984;73:276-8.

4. Douglas BK, Silverman DG, Weinberg H. Perfusion washout: increasing a microvascular free flap tolerance to ischemia. J Reconstr Microsurg. 1989;5:151-5.

5. Israeli D, Senderoff DM, Zhang WX, Urken ML, Weinberg $H$. Enhancement of fluorescein perfusion in experimental skin flaps following postischemic washout with iloprost, urokinase, verapamil, and University of Wisconsin solution. J Reconstr Microsurg. 1993;9:435-9.

6. Zaccaria A, Weinzweig N, Yoshitake M, Matsuda T, Cohen $M$. Vitamin $C$ reduces ischemia-reperfusion injury in a rat epigastric island skin flap model. Ann Plast Surg. 1994;33:620-3.

7. Fu W, Jiao X. The effect of mannitol and anisodamin on the prevention of free radical injury to post-ischaemia flaps: an experimental study. Br J Plast Surg. 1995;48:218-21.

8. Cetinkale O, Bilgic L, Bolayirli M, Sengul R, Ayan F, Burcak G. Involvement of neutrophils in ischemia-reperfusion injury of inguinal island skin flaps in rats. Plast Reconstr Surg. 1998;102:153-60.

9. Willemart G, Knight KR, Morrison WA. Dexamethasone treatment prior to reperfusion improves the survival of skin flaps subjected to secondary venous ischaemia. $\mathrm{Br}$
J Plast Surg. 1998;51:624-8.

10. Cordeiro PG, Lee JJ, Mastorakos D, Hu QY, Pinto JT, Santamaria E. Prevention of ischemia-reperfusion injury in a rat skin flap model: the role of mast cells, cromolyn sodium, and histamine receptor blockade. Plast Reconstr Surg. 2000;105:654-9.

11. Bilgin-Karabulut A, Ademoglu E, Aydin I, Erer M, Gokkusu C. Protective effects of vitamins A and E pretreatment in venous ischemia/reperfusion injury. J Reconstr Microsurg. 2001;17:425-9.

12. Hong JP, Chung YK, Chung SH. The effect of prostaglandin E1 versus ischemia-reperfusion injury of musculocutaneous flaps. Ann Plast Surg. 2001;47:316-21.

13. Kara IG, Kara CO, Ozden A, Ocsel H. The effect of trimetazidine on the survival of rat island skin flaps subjected to ischemia-reperfusion injury. Ann Plast Surg. 2001;47:168-71.

14. Khiabani KT, Kerrigan CL. The effects of the nitric oxide donor SIN-1 on ischemia-reperfused cutaneous and myocutaneous flaps. Plast Reconstr Surg. 2002;110:169-76.

15. Mittermayr R, Valentini D, Fitzal F, Hallstrom S, Gasser $\mathrm{H}$, Redl H. Protective effect of a novel NO-donor on ischemia/reperfusion injury in a rat epigastric flap model. Wound Repair Regen. 2003;11:3-10.

16. Kuo YR, Jeng SF, Wang FS, Huang HC, Wei FC, Yang KD. Platelet glycoprotein IIb/IIIa receptor antagonist (abciximab) inhibited platelet activation and promoted skin flap survival after ischemia/reperfusion injury. J Surg Res. 2002;107:50-5.

17. Kuo YR, Wang FS, Jeng SF, Huang HC, Wei FC, Yang KD. Nitrosoglutathione modulation of platelet activation and nitric oxide synthase expression in promotion of flap survival after ischemia/reperfusion injury. J Surg Res. 2004;119:92-9.

18. Akamatsu J, Ueda K, Tajima S, Nozawa M. Sulfatide elongates dorsal skin flap survival in rats. J Surg Res. 2000;92:36-9.

19. Ueda K, Nozawa M, Miyasaka M, Akamatsu J, Tajima S. Sulfatide protects rat skin flaps against ischemiareperfusion injury. J Surg Res. 1998;80:200-4.

20. Cetin C, Kose AA, Aral E, Colak O, Ercel C, Karabagli Y, Alatas O, Eker A. Protective effect of fucoidin (a neutrophil rolling inhibitor) on ischemia reperfusion injury: experimental study in rat epigastric island flaps. Ann Plast Surg. 2001;47:540-6.

21. Abla LEF, Gomes HC, Percario S, Ferreira LM. Acetylcysteine in random skin flap in rats. Acta Cir Bras. [serial on the Internet] 2005 Mar-Apr;20(2).

22. Rumbolo PM, Cooley BC, Hanel DP, Gould JS. Comparison of the influence of intralumenal irrigation solutions on free flap survival. Microsurgery. 1992;13:45-7.

23. Wang HJ, Chen TM, Chow LS, Cheng TY, Chen JL. Recipient bed vascularity and the survival of ischaemic flaps. Br J Plast Surg. 1997;50:266-71.

24. Deune EG, Khouri RK. Rat strain differences in flap tolerance to ischemia. Microsurgery. 1995;16:765-7.

25. Fontana C, Komatsu CA, Pigozzi E, Gemperli R, Ferreira MC. [The use of MPG in preventing the post-reperfusion injury of an epigastric island flap: an experimental study in rats]. Rev Hosp Clin Fac Med Sao Paulo. 1992;47:264-8. 
26. Kohout M, Lepore DA, Knight KR, Van Gelder J, O’Brien BM, Stewart AG, Morrison WA. Cool perfusion solutions for skin flaps: a new mixture of pharmacological agents which improves skin flap viability. Br J Plast Surg. 1995;48:132-44.

27. Wang BH, Ye C, Stagg CA, Lin M, Fawcett T, VanderKolk CA, Udelsman R. Improved free musculocutaneous flap survival with induction of heat shock protein. Plast Reconstr Surg. 1998;101:776-84.

28. Sasaki GH, Pang CY. Hemodynamics and viability of acute neurovascular island skin flaps in rats. Plast Reconstr Surg. 1980;65:152-8.

29. Niki E. Action of ascorbic acid as a scavenger of active and stable oxygen radicals. Am J Clin Nutr. 1991;54:1119S-1124S.

30. Yoshida W. Free radicals in the ischemia and reperfusion syndrome. Cir Vasc Angiol. 1996;12:82-95.

31. Ouriel K, Ginsburg ME, Patti CS, Pearce FJ, Hicks GL. Preservation of myocardial function with mannitol reperfusate. Circulation. 1985;72:II254-8.

32. Paterson IS, Klausner JM, Goldman G, Pugatch R, Feingold H, Allen P, Mannick JA, Valeri CR, Shepro D, Hechtman HB. Pulmonary edema after aneurysm surgery is modified by mannitol. Ann Surg. 1989;210:796-801.

33. Chait LA, May JW, Jr., O’Brien BM, Hurley JV. The effects of the perfusion of various solutions on the noreflow phenomenon in experimental free flaps. Plast Reconstr Surg. 1978;61:421-30.

34. Rosen HM, Slivjak MJ, McBrearty FX. The role of perfusion washout in limb revascularization procedures. Plast Reconstr Surg. 1987;80:595-605.

35. Magovern GJ, Jr., Bolling SF, Casale AS, Bulkley BH, Gardner TJ. The mechanism of mannitol in reducing ischemic injury: hyperosmolarity or hydroxyl scavenger? Circulation. 1984;70:191-5.

36. Oredsson S, Plate G, Qvarfordt P. The effect of mannitol on reperfusion injury and postischaemic compartment pressure in skeletal muscle. Eur J Vasc Surg. 1994;8:326-31.

37. Ueno T, Furukawa K, Katayama Y, Suda H, Itoh T. Spinal cord protection: development of a paraplegia-preventive solution. Ann Thorac Surg. 1994;58:116-20.

38. Yokoyama K, Nakamura K, Itoman M, Kimura M, Ohyatsu Y, Ui K, Wakita R. Do superoxide radicals in blood indicate anastomotic patency after microvascular tissue reperfusion? J Reconstr Microsurg. 1995;11:467-71.

39. Tortolani AJ, Powell SR, Misik V, Weglicki WB, Pogo GJ, Kramer JH. Detection of alkoxyl and carbon-centered free radicals in coronary sinus blood from patients undergoing elective cardioplegia. Free Radic Biol Med. 1993;14:421-6.

\section{Correspondence:}

Winston Bonetti Yoshida, MD

Depto de Cirurgia e Ortopedia

Faculdade de Medicina de Botucatu

Universidade Estadual Paulista- Unesp

18618-970 Botucatu - SP Brasil

Phone: (5514)3811-6269

Fax:(5514)3815-7428

winston@fmb.unesp.br
Conflict of interest: none Financial source: none

Received: April 12, 2005

Review: May 17, 2005

Accepted: June 14, 2005

\section{How to cite this article:}

Yoshida WB, Campos EBP. Ischemia and reperfusion in skin flaps: effects of mannitol and vitamin C in reducing necrosis area in a rat experimental model. Acta Cir Bras. [serial on the Internet] 2005 Sept-Oct;20(5). Available from URL: http://www.scielo.br/acb

*Color figure available from http://www.scielo.br/acb

\section{VANCOUVER 2004: O QUE MUDOU NAS REFERÊNCIAS}

As abreviaturas dos periódicos cumprem o INDEX MEDICUS.

ATENÇÃO: Após a última abreviatura do título do periódico (ou com título sem abreviatura) incluir um ponto final.

Consultar exemplar recente da Acta Cirúrgica Brasileira para servir de modelo. 